\title{
Adaptation and validation of the Brazilian Portuguese version of the Leader Empowering Behavior scale
}

\author{
Adaptação e validação da versão em português do Brasil da escala Leader Empowering Behaviour \\ Adaptación y validación de la versión en portugués brasileño de la escala Leader Empowering Behavior
}

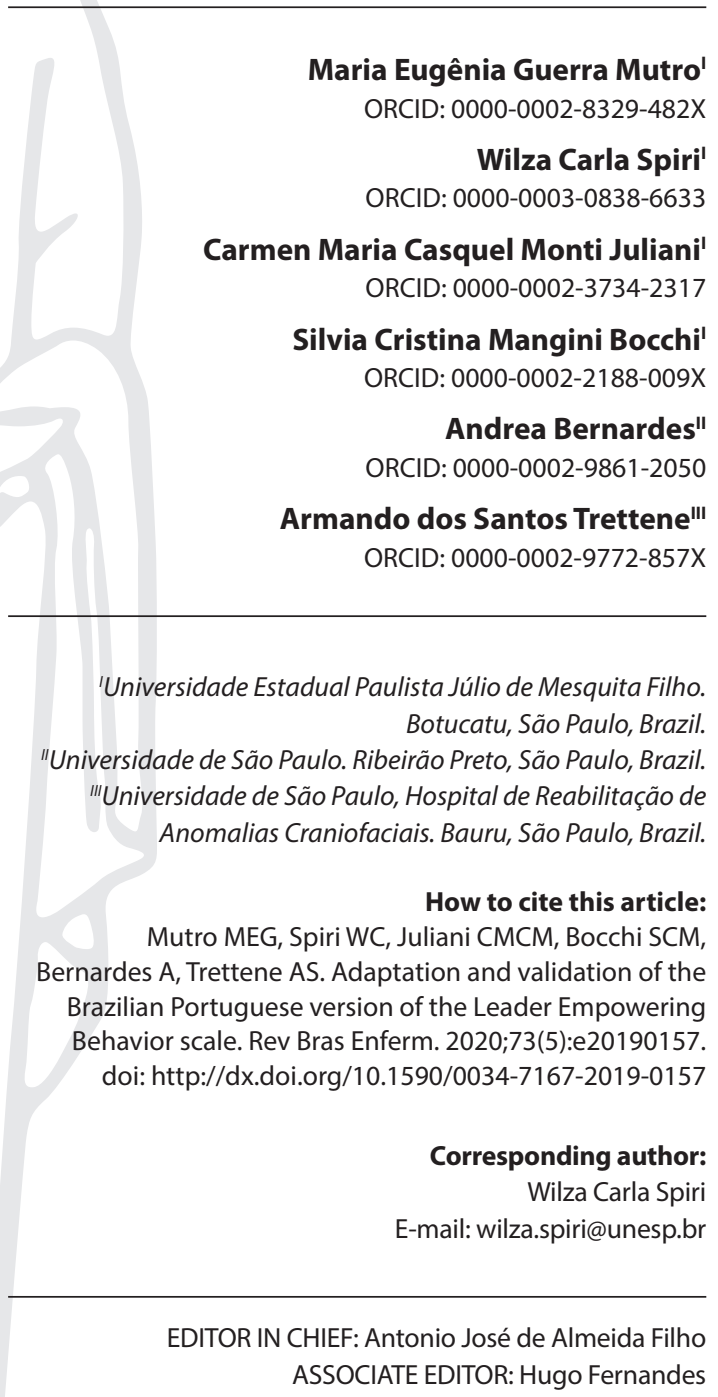

Submission: 03-04-2019

Approval: 12-02-2019

\begin{abstract}
Objectives: to adapt and validate the Leader Empowering Behavior scale for Brazilian Portuguese in a sample of Brazilian nurses. Methods: cross-sectional study through translation, backtranslation, expert evaluation, application and analysis of content, criteria and construct of the scale. Results: the title of the final version was Comportamento Empoderador do Líder. The equivalence evaluation presented Content Validity Index of $89 \%$ among the 27 items of the original scale and was applied to 272 nurses. For the construct validation, psychometric analyzes were performed; through calculations of the measure of sampling adequacy, were excluded six items from the translated instrument; and in the factor analysis, four factors were retained. The Cronbach's alpha was calculated for the four domains and ranged from 0.82 to 0.87 , demonstrating the scale reliability. Conclusions: the adapted version presented validity and reliability criteria for use in Brazil. Its use will make it possible to know the behavior of leaders to empower their team. Descriptors: Validation Studies; Leadership; Professional Practice Management; Power; Nursing Administration Research.
\end{abstract}

\section{RESUMO}

Objetivos: adaptar e validar para o português do Brasil a escala Leader Empowering Behaviour em uma amostra de enfermeiros brasileiros. Métodos: estudo transversal, por meio de tradução, retrotradução, avaliação por especialistas, aplicação e análise de conteúdo, critério e constructo da escala. Resultados: o título da versão final foi Comportamento Empoderador do Líder. A avaliação das equivalências apresentou Índice de Validade de Conteúdo de $89 \%$ entre os 27 itens da escala original e foi aplicada a 272 enfermeiros. Para a validação do constructo, foram feitas análises psicométricas, os cálculos da medida de adequação da amostra excluíram seis itens do instrumento traduzido e na análise fatorial, quatro fatores foram retidos. $\mathrm{O}$ alfa de Cronbach foi calculado para os quatro domínios e variou de 0,82 a 0,87, demonstrando a confiabilidade da escala. Conclusões: a versão adaptada apresentou critérios de validade e confiabilidade para uso no Brasil. Sua utilização possibilitará conhecer o comportamento do líder para empoderar sua equipe.

Descritores: Estudos de Validação; Liderança; Gerenciamento da Prática Profissional; Poder; Pesquisa em Administração de Enfermagem.

\section{RESUMEN}

Objetivos: adaptary validar la escala LeaderEmpowering Behavior para el portugués brasileño en una muestra de enfermeros brasileños. Métodos: estudio transversal a través de la traducción retrotraducción, evaluación experta, aplicación y análisis de contenido, criterios y del constructo de la escala. Resultados: el título de la versión final fue Comportamento Empoderador do Líder. La evaluación de equivalencia presentó un índice de validez de contenido del 89\% entre los 27 ítems de la escala original y se aplicó a 272 enfermeros. Para validar el constructo, se realizaron análisis psicométricos; los cálculos de medida de la adecuación muestral excluyeron seis ítems del instrumento traducido; y en el análisis factorial, se retuvieron cuatro factores. El alfa de Cronbach se calculó para los cuatro dominios y osciló entre 0,82 y 0,87, lo que demuestra la confiabilidad de la escala. Conclusiones: la versión adaptada presentó criterios de validez y confiabilidad para su uso en Brasil. Su uso permitirá conocer el comportamiento del líder para empoderar a su equipo.

Descriptores: Estudios de Validación; Liderazgo; Gestión de la Práctica Profesional; Poder; Investigación en Administración de Enfermería. 


\section{INTRODUCTION}

In recent decades, there has been a growing interest in the concept of innovative leadership in areas of management practice, and in the concept of empowerment related to this practice among professionals and managers in various areas.

The emerging empowerment construct framework shows the reasons for developing an instrument that analyzes the practice of empowering subordinates as a core component of the management and effectiveness of organizations. The construct highlights the growth of production and efficiency with the power sharing between supervisors and subordinates. In addition, experiences of team building within organizations suggest that empowerment techniques play a crucial role in group development ${ }^{(1)}$.

In 1994, as a requirement for a doctorate in management at the University of Indiana (USA), Chin Hui built and validated a scale in English named Leader Empowering Behavior (LEB) to assess empowering behaviors ${ }^{(2)}$.

This scale has been widely used in nursing research and demonstrated the following: higher success of innovations in management and patient care in an empowered team ${ }^{(3)}$; a positive association between the empowering behavior of the leader and the efficiency of nursing teams ${ }^{(4)}$; the promotion of job satisfaction ${ }^{(5-6)}$; and higher professional commitment of the entire team ${ }^{(7-8)}$.

Also in this perspective, in a study, empowerment was related to higher creativity of employees and nurses, and was found an association of empowering behaviors of the leader with important results of employee efficiency ${ }^{(9)}$. The behavior of the leader enables a favorable work environment, increases the quality level, patient safety, performance to reach the goals and job satisfaction ${ }^{(7,10)}$.

In the international literature, studies have been conducted because this subject is considered relevant and conducive to the development of the nursing management process $s^{(9-11)}$.

Nursing management researchers at a Canadian university have developed a leadership training project with first-line nurse leaders ${ }^{(12)}$. The LEB scale was used to analyze these managers'self-assessment regarding their empowerment behavior and its reflection on teams.

When considering the relevance of empowerment for the nurses' management process and the use of the LEB scale for the nursing practice in the international context, the following question was raised: can the LEB scale be used by nursing professionals in Brazil?

Given this gap knowledge in Brazil, the purpose of this study is to provide an accurate and reliable tool that offers insight into leaders' behavior to empower their team.

\section{OBJECTIVES}

To adapt and validate the Leader Empowering Behavior scale for Brazilian Portuguese in a sample of Brazilian nurses.

\section{METHODS}

\section{Ethical aspects}

The study was developed after authorization of the author of the original scale and approval by the Research Ethics Committee of the Botucatu Medical School, Universidade Estadual Paulista.
Data were voluntarily provided by participants when they agreed to participate in the study and signed the Informed Consent form.

\section{Design, place and period of study}

This is a cross-sectional study of cultural adaptation of an instrument in English to the Brazilian Portuguese language in order to achieve content, criterion and construct validity. In this type of study, the researcher aims to develop a reliable, accurate and usable instrument that can be used by other researchers ${ }^{(13)}$.

The framework adopted involved the steps of translation, back-translation, analysis by a committee of judges, application, psychometric analysis and a new authorization by the author to use the adapted version ${ }^{(14-15)}$.

Data were collected between November 2015 and November 2017 from nurses working in health units of the Healthcare Network 9, which covers 68 municipalities in the state of São Paulo, Brazil.

\section{Participants, inclusion and exclusion criteria}

The study included three types of participants: translators, judges and nurses.

Translators were conveniently selected according to the cultural adaptation framework for instruments ${ }^{(14-15)}$.

The panel of judges consisted of a convenience sample of three people, including two nurse teachers and health management specialists and one expert professor in the study methodology, all fluent in English.

The adapted version was applied in the pretest and validated (face validation) by 54 nurses, who considered it easy to understand and applicable to the Brazilian reality. There was no need for changes after the pretest application, thereby allowing the inclusion of these nurses as study participants.

The sample size calculation considered the reference of ten participants for each instrument item ${ }^{(16)}$, estimating the number of 270 subjects. Thus, 272 nurses participated and composed a non-probabilistic sample.

The inclusion criteria were nurses with an experience period of one year or more who belonged to the Healthcare Network 9.

\section{Data collection and analysis procedures}

The LEB scale originally contains 27 items divided into five domains. Responses are of a Likert scale type, ranging from one to seven points, and the following options: strongly agree (seven points); partially agree (six points); agree (five points), neither agree nor disagree (four points), disagree (three points), partially disagree (two points) and strongly disagree (one point). The higher the score the greater the presence of favorable attributes to the practice of empowerment ${ }^{(2)}$.

The methodological steps for cross-cultural adaptation consisted of the translation of the LEB scale to the target language (Portuguese) by two translators (T1 and T2) fluent in English, who had Brazilian Portuguese as their mother tongue. Only one of them was informed about the concepts and objectives of the study.

The two versions were analyzed and compared by the researchers, any doubts were solved together with the translators and the 
synthesis of the two versions was obtained $(T 1,2)$. Subsequently, the Portuguese synthesis version was translated back into English (back translation) by two American translators (R1 and R2), English native speakers, currently residing in Brazil and who were not informed about the purpose of the instrument.

The committee of judges evaluated the translated version for semantic, idiomatic, cultural and conceptual equivalence after receiving all versions and the spreadsheet with guidelines for completing the equivalences of each item separately.

For the analysis of judges, was considered the Content Validity Index (CVI) that measures the proportion or percentage of judges in agreement on certain aspects of the instrument and its items ${ }^{(17)}$. In order to stipulate the acceptable agreement rate among judges, recommended values of at least 0.80 between them were established as a decision criterion on the relevance and/or acceptance of the item ${ }^{(17-18)}$.

Thus, the 27-item Portuguese (T3) version of the instrument was consolidated and digitized for the Survey Monkey, which is a site for instrument creation and automatic e-mailing. The version was applied to nurses participating in the study.

After application of the instrument, the psychometric analysis was performed by adopting the Principal Component Analysis (PCA) for factor extraction. We considered only factors with eigenvalues greater than 1 and the anti-image correlation matrix, which is a way of obtaining evidence of the need to eliminate a certain variable from the model. For the calculation, the Measure of Sampling Adequacy (MSA) was used for each variable. In Exploratory Factor Analysis (EFA), we used the Kaiser-Meyer-Olkin (KMO), which is the sampling adequacy index, and the Bartlett Sphericity Test, which evaluates the general significance of all correlations in a data matrix ${ }^{(19-20)}$.

Reliability was analyzed using internal consistency measured by Cronbach's alpha coefficient, which ranges from 0 to 1 . Values above 0.70 were considered satisfactory and values equal to or above 0.80 were excellent ${ }^{(21)}$.

The Statistical Package for the Social Sciences (SPSS), version 22.0 was used in the analyzes.

\section{RESULTS}

The synthesis of Brazilian Portuguese versions was analyzed by the judges with a mean agreement of $86.8 \%$. Neither a second round of full analysis nor a new process of translating the instrument items were needed.

The idiomatic equivalence presented the highest agreement index with $89.7 \%$, followed by conceptual equivalence with $88.6 \%$, cultural with $87.4 \%$ and semantics with $81.8 \%$. The similarities between the judges' suggestions were considered definitive for the translated version for the pretest (T3).

The synthesis version after analysis by the judges was called 'Comportamento Empoderador do Líder' - CEL* scale, as shown in Figure 1.

The scale was applied to a sample of 272 nurses. The characterization of participants showed their age was between 31 and 40 years (43.7\%); $57 \%$ held leadership positions (boss, person in charge, technical manager, supervisor); $57 \%$ had a specialization postgraduate degree and $26 \%$ had a master's degree; $46 \%$ worked 40 hours a week and $22 \%$ had two employment engagements.

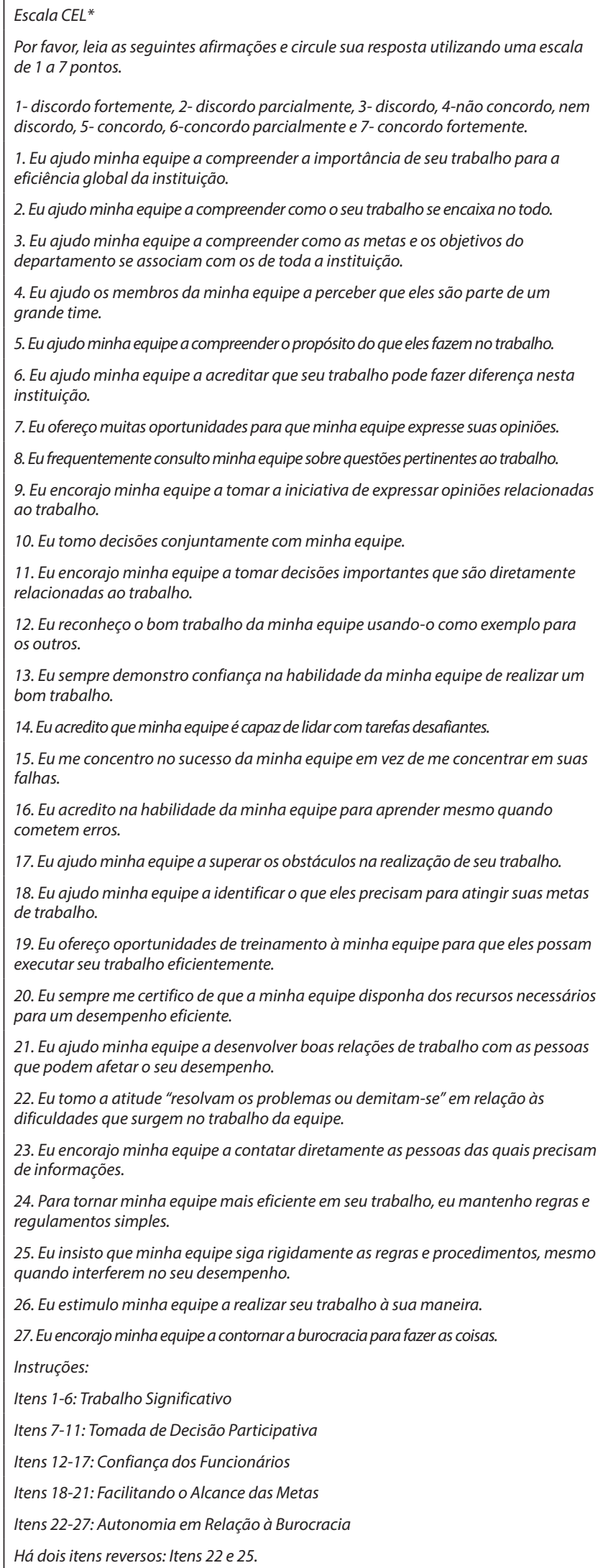

12. Eu reconheço o bom trabalho da minha equipe usando-o como exemplo para os outros.

13. Eu sempre demonstro confiança na habilidade da minha equipe de realizar um bom trabalho.

14. Eu acredito que minha equipe é capaz de lidar com tarefas desafiantes.

15. Eu me concentro no sucesso da minha equipe em vez de me concentrar em suas falhas.

16. Eu acredito na habilidade da minha equipe para aprender mesmo quando cometem erros.

17. Eu ajudo minha equipe a superar os obstáculos na realização de seu trabalho.

18. Eu ajudo minha equipe a identificar o que eles precisam para atingir suas metas de trabalho.

19. Eu ofereço oportunidades de treinamento à minha equipe para que eles possam executar seu trabalho eficientemente.

20. Eu sempre me certifico de que a minha equipe disponha dos recursos necessários para um desempenho eficiente.

21. Eu ajudo minha equipe a desenvolver boas relações de trabalho com as pessoas que podem afetar o seu desempenho.

22. Eu tomo a atitude "resolvam os problemas ou demitam-se" em relação às dificuldades que surgem no trabalho da equipe.

23. Eu encorajo minha equipe a contatar diretamente as pessoas das quais precisam de informações.

24. Para tornar minha equipe mais eficiente em seu trabalho, eu mantenho regras e regulamentos simples.

25. Eu insisto que minha equipe siga rigidamente as regras e procedimentos, mesmo quando interferem no seu desempenho.

26. Eu estimulo minha equipe a realizar seu trabalho à sua maneira.

27. Eu encorajo minha equipe a contornar a burocracia para fazer as coisas. Instruções:

Itens 1-6: Trabalho Significativo

Itens 7-11: Tomada de Decisão Participativa

Itens 12-17: Confiança dos Funcionários

Itens 18-21: Facilitando o Alcance das Metas

Itens 22-27: Autonomia em Relação à Burocracia

Há dois itens reversos: Itens 22 e 25.

Note: *CEL - Comportamento Empoderador do Líder (Brazilian Portuguese version of the LEB scale). Figure 1 - Translated and adapted version of the scale after judges' evaluation of semantic, idiomatic, cultural and conceptual equivalence, Botucatu, São Paulo, Brazil, 2017 
Table 1 presents the mean and standard deviation of the CEL scale domains.

In the psychometric analyzes, the Principal Component Analysis (PCA) allowed identifying the basic information related to the coherence between answers given to items. Four out of the five factors (Domains) fit well with the sample used. Domain 5 (Autonomia em Relação à Burocracia) did not achieve good results, because its values did not reach a good fit for this sample, from the anti-image analysis of the correlation matrix, and it was removed from subsequent analyzes.

Table 1 - Mean of the CEL scale domains, Botucatu, São Paulo, Brazil, 2017

\begin{tabular}{lcc}
\hline CEL score/item & Mean \pm sd & Median (Min- Max) \\
\hline Trabalho Significativo & $5.91 \pm 0.69$ & $6.00(3.80-6.70)$ \\
Tomada de decisão Participativa & $5.87 \pm 0.79$ & $5.80(3.60-7.00)$ \\
Confiança dos Funcionários & $5.81 \pm 0.81$ & $5.80(2.70-7.00)$ \\
Facilitando o alcance de metas & $5.73 \pm 0.86$ & $5.65(3.30-7.00)$ \\
Autonomia em relação à burocracia & $4.60 \pm 0.70$ & $4.50(2.80-6.70)$ \\
Overall & $5.56 \pm 0.58$ & $5.50(3.90-6.80)$ \\
\hline
\end{tabular}

Note: CEL - Comportamento Empoderador do Lider (Brazilian Portuguese version of the LEB scale).

Table 2 - Internal reliability results, according to the new arrangement of items by domain of the CEL scale, Botucatu, São Paulo, Brazil, 2017

\begin{tabular}{lc}
\hline Domains & Cronbach's alpha \\
\hline 1. Trabalho Significativo & 0.87 \\
2. Tomada de Decisão Participativa & 0.82 \\
3. Confiança dos Funcionários & 0.82 \\
4. Facilitando o Alcance das Metas & 0.83 \\
\hline
\end{tabular}

Table 3 - Results of the number of items and new arrangement by domains, Botucatu, São Paulo, Brazil, 2017

\begin{tabular}{llc}
\hline Domains & Items & $\begin{array}{c}\text { New item } \\
\text { numbering }\end{array}$ \\
\hline $\begin{array}{l}\text { 1.Trabalho } \\
\text { Significativo }\end{array}$ & $\begin{array}{l}\text { 2. Eu ajudo minha equipe a compreender } \\
\text { como o seu trabalho se encaixa no todo } \\
\text { 3. Eu ajudo minha equipe a compreender } \\
\text { como as metas e os objetivos do } \\
\text { departamento se associam com os de toda a } \\
\text { instituição }\end{array}$ & 2 \\
& $\begin{array}{l}\text { 4. Eu ajudo os membros da minha equipe a } \\
\text { perceber que eles são parte de um grande } \\
\text { time }\end{array}$ & 3 \\
& $\begin{array}{l}\text { 5. Eu ajudo minha equipe a compreender o } \\
\text { propósito do que eles fazem no trabalho }\end{array}$ & 4 \\
2. Tomada & $\begin{array}{l}\text { 7. Eu ofereço muitas oportunidades para que } \\
\text { minha equipe expresse suas opiniões } \\
\text { Participativa }\end{array}$ & 5 \\
& $\begin{array}{l}\text { 8. Eu frequentemente consulto minha equipe } \\
\text { sobre questões pertinentes ao trabalho } \\
\text { 9. Eu encorajo minha equipe a tomara } \\
\text { iniciativa de expressar opiniões relacionadas } \\
\text { ao trabalho } \\
\text { 10. Eu tomo decisões conjuntamente com } \\
\text { minha equipe } \\
\text { 11. Eu encorajo minha equipe a tomar } \\
\text { decisões importantes que são diretamente } \\
\text { relacionadas ao trabalho. }\end{array}$ & 6 \\
\hline & 8 \\
\hline
\end{tabular}

Table 3 (concluded)

Domains Items $\begin{gathered}\text { New item } \\ \text { numbering }\end{gathered}$

3. Confiança $\quad$ 13. Eu sempre demonstro confiança na 10

dos habilidade da minha equipe de realizar um

Funcionários bom trabalho

14. Eu acredito que minha equipe é capaz de lidar com tarefas desafiantes

15. Eu me concentro no sucesso da minha equipe em vez de me concentrar em suas falhas

16. Eu acredito na habilidade da minha equipe para aprender mesmo quando cometem erros

19. Eu ofereço oportunidades de treinamento à minha equipe para que eles possam executar seu trabalho eficientemente

20. Eu sempre me certifico de que a minha equipe disponha dos recursos necessários para um desempenho eficiente

4. Facilitando 6. Eu ajudo minha equipe a acreditar que o Alcance das seu trabalho pode fazer diferença nesta Metas instituição

12. Eu reconheço o bom trabalho da minha equipe usando-o como exemplo para os outros 17. Eu ajudo minha equipe a superar os obstáculos na realização de seu trabalho

18. Eu ajudo minha equipe a identificar o que eles precisam para atingir suas metas de trabalho

21. Eu ajudo minha equipe a desenvolver boas relações de trabalho com as pessoas que podem afetar o seu desempenho

24. Para tornar minha equipe mais eficiente em seu trabalho, eu mantenho regras e regulamentos simples

12
The adequacy coefficient $\mathrm{KMO}(\mathrm{KMO}=.893)$ and the Bartlett's test (Bartlett=1544.590, df: 210, p<.000) were significant for the CEL scale items, accepting the possibility of factoring the data matrix.

The factor analysis showed that the scale contained 21 items included in four domains, as follows: Trabalho Significativo, Tomada de Decisão Participativa, Confiança dos Funcionários and Facilitando o Alcance das Metas.

Thus, from the factor analysis, considering the 21 items of the scale, Cronbach's alpha values were calculated for the four domains, as shown in Table 2.

After psychometric analysis of the sample of nurses of the Healthcare Network 9 participating in this study, the CEL scale was validated with four domains and 21 items, as shown in Table 3.

\section{DISCUSSION}

The cross-cultural adaptation has become a challenge due to the still incipient research on the theme in Brazil. However, in other countries, especially Canada, for years scholars have linked the LEB scale to other behaviors or scales for the assessment of team performance ${ }^{(3-4,9-10,22-23)}$.

During the construction of the $\mathrm{LEB}^{(2)}$ were performed similar psychometric analyzes to those of the present study and in the overall score of the scale, a Cronbach's alpha of 0.71 was found. In studies conducted in Canada ${ }^{(3-4,9-10)}$ neither the version nor the cultural adaptation of the LEB scale were performed, but the 
reliability measured by Cronbach's alpha showed the following results: $0.97^{(3)}, 0.63-0.96^{(4)}, 0.96^{(9)}$ and $0.84^{(9)}$, demonstrating the internal consistency of this scale.

The LEB scale has been used in studies conducted in countries where English is not the mother tongue, such as Pakistan ${ }^{(22)}$ and $J^{\prime}{ }^{2}{ }^{(23)}$. In the study in Pakistan, it was not clear whether the version and adaptation of the scale were performed. The only reference was made to an instrument that allowed to know the leaders' behavior for the empowerment of their team ${ }^{(23)}$.

In the study conducted in Jordan, was not performed the version and/or adaptation of the scale. According to the authors, the nurses who answered the instrument were able to read and understand English and this is the official language in nursing education in Jordan. The reliability of the LEB scale measured by Cronbach's alpha was between 0.89 and $0.95^{(23)}$.

In the present study, the process of choosing the instrument, originally in English, triggered the process of translation and cross-cultural adaptation. Given the cultural and language differences, a simple translation cannot be performed, and technical, linguistic and semantic aspects must be considered ${ }^{(15)}$.

The analysis of judges through calculation of the CVI allowed a qualitative analysis of the translation process and, consequently, the application of the scale among participants for the construct validation. When performing the equivalence of an instrument, a multidisciplinary committee should be chosen to obtain the semantic, idiomatic, cultural and conceptual validity of items between the original and adapted versions ${ }^{(14)}$. The present study corroborates the literature, which indicates the composition of the committee by at least one expert in the study methodology, a health professional and a professional with mastery in the source language of the instrument ${ }^{(15)}$.

The version produced by expert consensus was applied in the pretest. This phase is important in the cross-cultural adaptation, which is aimed at assessing the understanding of items of the translated instrument and its acceptability ${ }^{(24)}$.

The application of the scale to the sample of 272 participants followed the literature recommendations of ten participants for each item of the instrument ${ }^{(16)}$.

The characteristics of the study participants highlighted the predominant age group of nurses of 31-40 years old, occupying leadership positions, with postgraduate studies (specialization and master's), and working 40 hours per week. These characteristics are corroborated by other studies of similar profile ${ }^{(25-26)}$.

In the statistical analysis, considering Likert-type responses from 1 (strongly disagree) to 7 (strongly agree), the total mean value of the CEL scale responses was 5.91 and the standard deviation (SD) was 0.69 , confirming an empowering behavior, since the closer to 7 , the more favorable attributes to the practice of empowerment ${ }^{(2)}$.

In two studies conducted in Ontario, Canada, the behavior of nurses considered leaders had LEB mean values of $3.69^{(3)}$ and 3.79(4), both classified as moderate empowerment.

In another study in Canada, also conducted with nurses, the applied LEB scale had a mean value of 4.84. Through this study, it was possible to know the behavior developed by leaders and associate it with structural and psychological empowerment and job satisfaction. The conclusion was that the empowering behavior of the leader influenced the relationship between leader and follower as a primary aspect of the team empowerment process, with consequent satisfaction in the work environment ${ }^{(9)}$.

In the province of British Columbia, Canada, the LEB scale was applied and the value varied according to the subscales. The subscale Autonomia em Relação à Burocracia (Domain 5) showed the lowest score (3.61) compared to other subscales that ranged from 5.50 to 5.95 , i.e., through these scores it was possible to infer an appropriate empowering behavior ${ }^{(10)}$.

In the study conducted in Jordan ${ }^{(23)}$, the LEB scale was associated with burnout and showed that nurses in this country suffer from high levels of burnout, reflected in the associations between emotional exhaustion and depersonalization. The conclusion was that empowered nurses reduce their feelings of burnout, which demonstrates the importance of the leader's role in the nursing work environment.

The significance of the LEB scale is noteworthy when relating nurses' engagement at work with their intention to remain in this job. Clearly, the empowering behavior enables nurses' adaptation to the rapid changes occurring in the complex health care environment. In conclusion, leaders play a key role in team empowerment and exert positive influence in team engagement and their continuity in the job, thereby ensuring better outcomes for the organization and patients ${ }^{(22)}$.

The psychometric analysis allowed the rearrangement of the scale domains. As established in the literature, the psychometric measurement presupposes validation in order to provide reliability ${ }^{(27)}$. Therefore, validating an instrument constitutes studying two fundamental characteristics: reliability and validity ${ }^{(28)}$.

The use of MSA allowed a consensus regarding the items that should compose the analysis matrix. The factors did not group identically to the original. Then, came the EFA confirming the existence of four domains, rather than five as the original structure of the LEB scale in English.

Through factor analysis, was explained the correlation or covariance between variables and a larger number of variables was reduced to a smaller number of factors. The explained variance percentage of $62 \%$ showed a good fit in data analysis. The higher the percentage of variance that a proposed model can explain, the more valid the model seems to be ${ }^{(20)}$.

The reliability calculated from Cronbach's alpha coefficient for the four domains of the 21-item instrument ranged from 0.82 to 0.87 , which indicates good internal consistency ${ }^{(21)}$.

The application of the scale allowed the self-assessment of care nurses and managers, as they all develop leadership roles in the various compositions of health teams. A health team composed of professionals with empowering behavior can converge on quality care, higher satisfaction ${ }^{(6-7)}$ and professional commitment ${ }^{(8-9)}$.

\section{Study limitation}

Although the study was conducted in a sample that attended the reference of ten participants for each item of the instrument, a larger sample could enable more robust statistical analysis.

\section{Contributions to the area of Nursing and health}

The study provides insights into the behavior of leaders in empowering their team through an instrument that can be 
self-applied. This allows that leaders and followers reflect about the attributes needed for the performance of professional activities.

In addition, the CEL scale can be used not only in nursing but also in the context of interprofessional health practice.

In international studies, the scale is widely used in correlations with other factors in the workplace, and in the Brazilian context, it can be used in a similar manner.

\section{CONCLUSIONS}

The results obtained in the adaptation and validation of the CEL scale provided evidence of the validity of its use as a tool when considering the empowering behavior as an innovative health management strategy model.

Study participants showed empowering behavior, because the overall mean score of the CEL scale was 5.56, close to the 7 score of the scale that demonstrates this behavior.

The LEB scale, originally developed in English, was culturally adapted in a sample of nurses and followed the steps recommended in the adopted methodological framework. Content validity was maintained, according to expert committee evaluation, the Cronbach's alpha value was adequate, and through adjustments in the EFA, there were changes in the structure initially adopted and it became a scale with four domains and 21 items.

The process of translation and validation has made available an instrument for assessing empowering behaviors of leaders. When considering the scenario and sample used, evaluating the use of the scale in practice depends on conducting new studies in different contexts and realities in order to consolidate its validation process.

\section{FUNDING/ACKNOWLEDGEMENT}

Conselho Nacional de Desenvolvimento Científico e Tecnológico - CNPq - Process: 304169/2018-8.

\section{ERRATUM}

Article "Adaptation and validation of the Brazilian Portuguese version of the Leader Empowering Behavior scale", with number of DOI: http://dx.doi. org/10.1590/0034-7167-2019-0157, published in the journal Revista Brasileira de Enfermagem, 73(5):e20190157, at the footer:

Where to read:

http://dx.doi.org/10.1590/0034-7167-2018-0757

Read:

http://dx.doi.org/10.1590/0034-7167-2019-0157

\section{REFERENCES}

1. Conger JA, Kanungo RN. The empowerment process: integrating theory and practice. Acad Manag Rev [Internet]. 1988. [cited 2018 Mar 29];13(3):471-82. Available from: https://www.jstor.org/tc/accept?origin=/stable/pdf/258093.pdf

2. Hui C. Effects of leadership empowerment behaviors and followers personal control, voice, and self-efficacy on n-role performance: an extension and empirical test of Conger and Kanungo's empowerment process model. 1994. Bloomington, IN: Indiana University; 1994.

3. Greco $P$, Laschinger HK, Wong C. Leader empowering behaviours, staff nurse empowerment and work engagement/burnout. Nurs Leadership. 2006;19(4):41-56.doi:10.12927/cjnl.2006.18599.

4. Laschinger HK, Wong C, McMahon L, Kaufmann C. Leader behavior impact on staff nurse empowerment, job tension, and work effectiveness. J Nurs Adm. 1999;29(5):28-39. doi: 10.1097/00005110-199905000-00005

5. Wong C, Laschinger HKS. Authentic leadership, performance and job satisfaction: the mediating role of empowerment. J Adv Nurs. 2013;69(4):947-59. doi: 10.1111/j.1365-2648.2012.06089.x

6. Wagner JI, Warren S, Cummings G, Smith DL, Olson JK. Resonant leadership, workplace empowerment, and "spirit at work": impact on registered nurses job satisfaction and organizational commitment. Can J Nurs Res. 2013;45(4):108-28. doi: 10.1177/084456211304500409

7. Asiri SA, Rohrer WW, Al-Surimi K, Da'ar OO, Ahmed A. The association of leadership styles and empowerment with nurses' organizational commitment in an acute health care setting: a cross-sectional study. BMC Nurs. 2016;15:38. doi: 10.1186/s12912-016-0161-7

8. Yong-Sook E, Young-Hae K, Nae-Young L. Path analysis of empowerment and work effectiveness among staff nurses. Asian Nurs Res. 2014;8:42-48. doi: 10.1016/j.anr.2014.02.001

9. Dahinten VS, Lee SE, MacPhee M. Disentangling the relationships between staff nurses' workplace empowerment and job satisfaction. J Nurs Manag. 2016 Nov; 24:1060-70. doi: 10.1111/jonm.12407

10. Havaei F, MacPhee M, Dahinten VS. Psychological Competence: the key to leader empowering behaviors. J Nurs Adm. 2014;44(5):276-283. doi: 10.1097/NNA.0000000000000067.

11. Regan S, Laschinger HKS, Wong CLA. The influence of empowerment, authentic leadership, and professional practice environments on nurses' perceived interprofessional collaboration. J Nurs Manage, 2016;24(1):E54-61. doi: 10.1111/jonm.12288

12. MacPhee $M$, Bouthillette F. Developing leadership in nurse managers: the british columbia nursing leadership institute. Nurs Leadersh. 2008;21(3):64-75. doi: 10.12927/cjnl.2008.20061 
13. Polit DF, Beck CT. Nursing Research: generating and assessing evidence for nursing practice. 8.ed. Philadelphia: Wolters Kluwer Healt; 2010.

14. Beaton DE, Bombardier C, Guillemin F, Ferraz MB. Guidelines for the process of cross-cultural adaptation of self-report measures. Spine. 2000;25(24):3186-91. doi: 10.1097/00007632-200012150-00014

15. Beaton D, Bombardier C, Guillemin F, Ferraz MB. Recommendations for the cross-cultural adaptation of the DASH \& QuickDASH outcome mesures contributors to this document [Internet]. Toronto: Institute for Work \& Health; 2007 [cited 2018 Apr 20]. Available from: http://www. dash.iwh.on.ca/sites/dash/files/downloads/cross_cultural_adaptation_2007.pdf

16. Hair Jr JF, Black WC, Babin BJ, Anderson RE, Tatham RL.Multivariate data analysis. 7 ed. New York: Prentice Hall; 2009.

17. Pasquali L. Instrumentação psicológica: fundamentos e prática. Porto Alegre: Artme; 2010.

18. Alexandre NMC, Coluci MZO.Content validity in the development and adaptation processes of measurement instruments. Ciênc Saúde Coletiva. 2011;16(7):3061-8. doi: 10.1590/S1413-81232011000800006

19. Tabachnick B, Fidell L.Using multivariate analysis. [Internet]. Los angeles: Harper Collins Publishers, 2007. [cited Nov 10 2017]. Available from: http://baunne.unne.edu.ar/documentos/EstadisticaMultivariable.pdf

20. Figueiredo DB. Uses of exploratory factorial analysis in psychology. Aval Psicol [Internet]. 2012 [cited Mar 29, 2018];11(2):213-228. Available from: http://pepsic.bvsalud.org/pdf/avp/v11n2/v11n2a07.pdf

21. Cronbach JL. Coefficient alpha and the internal structure of tests. Psychometrika [Internet]. 1951 [cited Nov 10 2017];16(3):297-334. Available from: https://pdfs.semanticscholar.org/e985/ac2e151903000cac310ffbc5b2cb4fbb9dd5.pdf

22. Bukhari N, Afzal M, Azhar M, Gilani SA. The Role of Nursing Leader Empowering Behavior on Work Engagement and Intent to Stay in Hospital. J Health Med Nurs [Internet]. 2018 [cited 2019 Feb 21]:54:40-3. Available from: https://iiste.org/Journals/index.php/JHMN/article/view/44311

23. Mudallal RH, Othman W, Hassan NFA. Nurses' burnout: the influence of leader empowering behaviours, work conditions, and demographic traits. J Health Care Org, Provision, Fin. 2017 54:1-10. doi: 10.1177/0046958017724944

24. Aires M, Dal Pizzol FLF, Mocellin D, Rosset I, Morais EP, Paskulin LMG. Cross-cultural adaptation of the Filial Responsibility protocol for use in Brazil. Rev Bras Enferm. 2017;70(6):1268-76. doi: 10.1590/0034-7167-2016-0479

25. Viana RAPP, Vargas MAO, Carmagnani MIS, Tanaka LH, Luz KR, Schmitt PH. Profile of an intensive care nurse in different regions of Brazil. Texto Contexto Enferm. 2014;23(1):151-59. doi: 10.1590/S0104-07072014000100018

26. Silva VLS, Camelo SHH, Soares MI, Resck ZMR, Chaves LDP, Santos FC, et al. Leadership Practices in Hospital Nursing: a self of manager nurses. Rev Esc Enferm USP. 2017;51:e03206. doi: 10.1590/s1980-220x2016099503206

27. Pasquali L. Psychometrics. Rev Esc Enferm USP. 2009;43(Esp.):992-999. doi: 10.1590/S0080-62342009000500002

28. DeVellis RF. Scale development theory and applications. 4ed. Los Angeles: Sage, 2017. 